\title{
Local Film Production in the Philippine Cordillera: Processes, Motivations, and Constraints
}

Jason Paolo Telles

\begin{abstract}
The local film production industries in the Philippine Cordillera region have been thriving since the 1980s. In Baguio City, Benguet, and Mountain Province, local filmmakers have already produced various cinematic forms such as documentary films, feature (short and full length) films, music videos, and animated films for various purposes. Utilizing political economy of media as a framework, this paper provides a preliminary exploration of the processes involved in the local production of those types of films in Baguio, Benguet, and Mountain Province. It also discusses the motivations and constraints that influence or inform the decisions and activities of local filmmakers in terms of content and production.
\end{abstract}

Keywords: Baguio, Benguet, Mountain Province, Cordillera films, Political Economy of Film 


\section{Plaridel Open Access Policy Statement}

As a service to authors, contributors, and the community, Plaridel: A Philippine Journal of Communication, Media, and Society provides open access to all its content. To ensure that all articles are accessible to readers and researchers, these are available for viewing and download (except Early View) from the Plaridel journal website, provided that the journal is properly cited as the original source and that the downloaded content is not modified or used for commercial purposes. Plaridel, published by the University of the Philippines College of Mass Communication is licensed under Creative Commons Attribution-NonCommercial-NoDerivatives 4.0 International License (https://creativecommons.org/ licenses/by-nc-nd/4.0/legalcode).

\section{How to cite this article in APA}

Telles, J. P. (2020). Local film production in the Philippine Cordillera: Processes, motivations, and constraints. Plaridel, 17(2), 99-122. http://www.plarideljournal.org/article/local-film-production-inthe-philippine-cordillera-processes-motivations-and-constraints/ 


\section{Film Production Landscape in the Cordillera Region}

Most of the provinces of the Cordillera Administrative Region (CAR) in the Northern Philippines have their own relatively active local mass media industries that cater to their information, education, entertainment, cultural mediation, and other needs and activities. The most widespread form of media in the region is radio broadcasting. In fact, Abra has at least seven AM and FM radio stations, Apayao has one, Kalinga has four, Mountain Province has four, Ifugao has two, and Benguet and Baguio City have more than 20 (OMICS International, 2014). Most of them are owned and operated by commercial radio companies while only a few have nonprofit orientations and are managed and operated by either the national government, local government units, state colleges, or religious organizations. Local privately owned newspapers, meanwhile, are also among those distributed for consumption in the region. The more popular local weeklies in the region are the Baguio Midland Courier, Northern Dispatch, The Mountain Province Exponent, Baguio Chronicle, and The Cordillera Today, among many others. Music recording also has a fair share of popularity in the region, especially in Baguio and Benguet. Finally, there is also a presence of film industries in almost all provinces in the Cordillera.

On August 6 to 9, 2015, the National Commission for Culture and the Arts' (NCCA) Cinema Rehiyon 7, with the theme "At the Crossroads of the Seventh Art," included the exhibition of Bosu: The Last Headhunter produced by Rosendo "Sendong" Salvacio and directed by Nestor "Boyong" Daguines, who are both of Kankana-ey descent. The NCCA described their film as "a perfect example of native indigenous film, produced by and for the Cordilleran community" (NCCA, 2015, para. 7). However, Daguines's and Salvacio's movie is but a mere glimpse of the whole local industry of film production in the Cordillera region.

Peoples of the Cordillera have already produced various types of films, including feature (both short and full-length), animated, and documentary films, as well as music videos, which this paper also considers as films, following Lev Manovich's (1999) explanation that they are "cinematic forms ... which are not linear narratives" (p. 184), and Xian-Sheng Hua and Lie Lu, Hong-Jiang Zhang's (2004) definition that music videos are short films that are "meant to present a visual representation of a popular music song" (p. 472).

In Baguio City and the province of Benguet alone, there emerged several individuals and small production businesses that have made films and music videos for local consumption. Below is a list of some of the more prominent production outfits in Baguio and Benguet: 
Table 1. List of some prominent production outfits in Baguio and Benguet

\begin{tabular}{|l|l|}
\hline Production Outfit & Owner/s \\
\hline Shapadoya Records & Sammy "Samiklad" Dangpa \\
\hline Awisan Video Works & Nestor Clemente \\
\hline Donpoen Productions & Nardo Dongpoen \\
\hline Highlander Videoworks & Roger Baiwes and Nestor Clemente \\
\hline Abatan Records & Marcons Dayaoen \\
\hline Apoy Production & Swing Tomas \\
\hline JG Production & Jun Garcia \\
\hline Bestac Production & Rudy Albino \\
\hline Quilito Production & Nilda Oloan \\
\hline Talaw Production & Rosendo “Sendong" Salvacio \\
\hline Anak di Cordillera / \\
Igorot Channel & Gerry Bestoca \\
\hline Kadontogan & \\
\hline Bigis & Cornelio Dampog \\
\hline RCO Production & Paul Masilem \\
\hline JLT Production & Ricky Alpindo \\
\hline Berlyson Production & Monnette Tami-ing \\
\hline Kinobouyan & Wilson Langpawen \\
\hline Kabenguetan Digital Productions & Hientjie Pis-oy \\
\hline RAL Production & Felimon Cariño \\
\hline lgorot Films & Richard Ligmayo \\
\hline & Nestor “Boyong” Daguines \\
\hline
\end{tabular}

According to Arthur "Art" Tibaldo (personal communication, April 21, 2018), Eric de Guia, popularly known as Kidlat Tahimik, could be considered the pioneer of independent filmmaking in the Cordilleras when he began to produce his own films such as Mababangong Bangungot (1977). De Guia could also be seen as instrumental in helping the locals of Baguio City and the province of Benguet realize that they, too, could produce their own films (A. Tibaldo, personal communication, April 21, 2018). In fact, Vicente G. Groyon (2014) describes Kidlat Tahimik as the model for local and even indigenous film producers and artists in the region and as "a creative organizing and guiding force" (p. 184) in the local film industry of the Cordilleras.

The first cinematic form to be produced in Baguio City and Benguet is the documentary film. In Baguio City, Tibaldo, who has a Bago lineage, was among the first locals who were able to produce their own documentary films. In 1984, he underwent a "Cinema Direct Workshop" held at the University of the Philippines College Baguio and made an output out of 
that activity about pocket miners in Benguet. It won in a nationwide film competition in 1985 ("Local Megmen Sweep Awards," 1985; A. Tibaldo, personal communication, April 21, 2018). In fact, his and other Baguio locals' documentaries won the top three major awards during the Fifth Manila Short-Film Festival in 1985. The films, which were also outputs from the aforementioned workshop, were Legacy of Filemon (1985) by Amelia Rogel-Rara, Apong Diano (1985) by Cooper Resabal, and Camote Miners (1985) by Tibaldo, which won the first, second, and third places, respectively, under the documentary category. According to a news report published at the now-defunct Baguio weekly The Gold Ore :

All three films dealt with subjects relative to the people of the Cordillera region. First prize winner, "Legacy of Filemon" by anthropologist Rara illustrates the rationale of the life of an Ibaloi family engaged on business in the city. Second place winner, "Apong Diano" by Resabal, a U.P. College Baguio instructor, shows an old man in the process of leaving the legacy of his ancestors to his grandchild and village and also portrays the fears and apprehensions of a society faced with the problem of cultural survival. Tibaldo's "Camote Miners" depicts the difficulties involved in native mining from the doghole tunnels to the processing of rough gold ores. ("Local megmen sweep awards in docu tilt," 1985, pp. 1,3)

The other entries under the category that were also made by Baguio locals were Baboo Mondonedo's Balodahi (1985), August Santiago's Kaigorotan (1985), and Tommy Hafalla's Mun Paot (1985) ("Local Megmen Sweep Awards, 1985). Tibaldo continued producing documentaries after that. An example of another one he made, Indigenous Forest Management (1999), was commissioned by the Department of Environment and Natural Resources, and it was about indigenous forest management practices in the Cordillera region. It was given the 1999 Best Documentary Award by the Film Academy of the Philippines.

The production of music videos by locals of Baguio and Benguet began in the early years of the 2000s through Nardo Dongpoen, Sammy "Samiklad" Dangpa, Raffy Manuel, Paul Masilem, and George Eng-enga. Dongpoen, who is considered as the first one to produce a music video in the province, was motivated by the aim to gain profit (R. Salvacio, personal communication, April 19, 2018; N. Daguines, personal communication, April 19, 2018). The same is true with other music video producers with the exception of Eng-enga, who is a pastor and who produced music videos of religious 
vernacular songs for the purposes of evangelism and communicating the Protestant faith to their audiences (De Velez, Domingo, \& Landicho, 2013). They were reproduced in VCD (eventually in DVD) format and distributed through house-to-house sales and through consignment with local music shops in various locations in Baguio, Benguet, and nearby provinces. The music videos included songs about love, history, modernity, environment, communal experiences, encounters with Christianity, and Igorot cultures and identities, among several others (Fong, 2007).

Meanwhile, the production of the first local feature films was primarily motivated by religious propaganda. Originally, the Lutheran church in the municipality of Buguias, Benguet, distributed English evangelical Christian or Bible-based films that were dubbed in the Kankana-ey language (Tindaan, 2010). Eventually, through the initiative of local Lutheran lay minister Sammy "Samiklad" Dangpa and the support of American Lutheran missionaries, the Vernacular Video Ministry or VVM was founded (Tindaan, 2010). Upon receiving positive feedback, the VVM was encouraged to produce more films, to burn those films in VCDs, and to make them available for purchase. Their production of local films began in 1993. Since then until 2008, they were able to make full-length ones with religious content in different languages in the Cordilleras such as Kankana-ey, Ibaloy, and Kalanguya (Tindaan, 2010).

Next, the Indigenous Film Productions or IFP based in Mankayan, Benguet, was established as a result of the realization of the economic potential of a local filmmaking business. The first film produced by the group was released in 2007 (Tindaan, 2010). In the same year, Gerry Agyao Bestoca (personal communication, May 3, 2018) also created his own film, Gasat (2007), for commercial purposes. Since then, other filmmakers have been encouraged to venture into this activity. For instance, Salvacio transformed his locally popular song "Talaw" into a movie of the same title, which eventually inspired Daguines to produce his own films as well (N. Daguines, personal communication, April 19, 2018; Matilla, 2015). Other filmmakers in the province followed suit.

Higher education institutions in Baguio with communication and media programs, namely the University of the Philippines Baguio, Saint Louis University, University of Baguio, and the University of the Cordilleras, also organized school-wide film festivals not only to showcase their students' outputs but also to boost the local film industry in the city. Meanwhile, the only animated videos produced locally are the Lampitok (2014) series made by Daguines and The Adventures of Laok and Lambino (2014) made by the RCO Records (N. Daguines, personal communication, April 19, 2018). 
In Mountain Province, local film production is gradually taking root. Currently, the most active local production outfit in the province is the Balangao Films led by Lemuel Fangonon from the municipality of Natonin. Since 2010, he had produced films such as Love Wish (2010), Cursing Whispers (2010), Rumah (2015), Artal (2016), Etherian (2016), Shoelace (2017), and A Warrior's Dad (2017). There is also John Glen Sobrevilla Sarol from the municipality of Bauko who made Mon (2017), Humaa ta et Bauko [For you, home] (2018), and Nagapwam? Diin ka Gikan? [Where are you from? Where have you been?] (2020). Also, an educational institution once produced a film for a competition. The Mountain Province General Comprehensive High School made the documentary Atsar (2018) that discusses the advocacy of a nurse in the Mountain Province about teenage pregnancy prevention and awareness of HIV and AIDS, for the National Adolescent Health and Development Film Festival in 2017 (Dagu-pen, 2017, p. 2). Director-producers Mark Lester Valle and Carla Samantha Pulido Ocampo, who have both been officially adopted in 2020 as Ifontok or children of Bontoc, through municipal council resolutions in Bontoc, have also produced multi-awarded films such as Walang Rape sa Bontok (2014) and Tokwifi (2019) that feature and represent the cultures of some indigenous peoples of the Mountain Province.

The province of Kalinga also has some locally produced films. An example is Kanana Kanu [And so, it was said] (2012) produced and directed by Jocelyn Banasan Kapuno from Pasil, Kalinga. There are also Kalimed (2007) and Killeg (2008) produced by Golda Mae "Kalimed" Bao-og Payong from the town of Lubuagan, Kalinga (Fong, 2014; Groyon, 2014). In Ifugao, there are also some individuals who have begun to take videos and photographs that aim to document their ways of life in their communities. In fact, Patrick Campos (2015) writes that the elders from Barangay Hapao in Hungduan, Ifugao "are now documentarians and photographers" (p. 70). Hapao locals such as Lopes Na-Uyac, a tribal leader, and Santos Bayucca, both of whom were influenced by Kidlat Tahimik, have taken footage of cultural activities in their community for the purposes of preserving it for their children (Campos, 2015).

Abra, meanwhile, just had some recent breakthroughs in their own local film industry. In 2018, Dexter Macaraeg founded Sine Abreño that presents the annual Abrenian Heritage Film Festival, where some films produced by residents of Abra are showcased (Cruz, 2020). As a director and producer, Macaraeg himself made local films such as Am-Amma [Heirloom] (2018), Tata Pilo (2019), and Balitok [Gold] (2016) that feature cultural activities and resistance in the province. In the 2020 installment of the festival, the documentary films that were shown are Abel Paoay (2020) by Melver Ritz 
Gomez, Stay Home (2020) by MJ Racadio, Asar (2020) by Jacinto Bose, Portero by Ed Patenio de Leon, Inkami Agklasen [Time for Class] (2020) by Edmar delos Santos, and 3 Minutes, 2 Mukha ng Buhay (2020) by James Merquise. The short films showcased were Tal-talon [Farm] (2020) by Rey Coloma, Toys Choices and Pandemic (2020) by Francis Balderas, Wakeup Call (2020) by Raymond Rinoza, Kulong: The Lockdown Story (2020) by Michael Daya, Patapaya (2020) by Edmar delos Santos, Full Storage (2020) by John Remel, Agape (2020) by Kristinen Angel Cerva, Ninlapu ken Magsawi [From Magsawi] (2020) by Ann M. Espelimbergo, Sa Apat na Sulok (2020) by Scarlett Mendoza, Oranje (2020) by Rolando Inocencio, Stay at Home/Stay at Hope (2020) by Julius Calera, and Kakaba-KABA-taan (2020) by RM Cruz. As of this writing, I have yet to confirm the presence of film producers and artists in Apayao.

\section{Filling in the Research Gap on Local Films in the Cordilleras}

This paper aims to provide a description of the local film production process being conducted by filmmakers in Baguio City, Benguet, and Mountain Province. It also features an analysis of the motivations and constraints that have influenced their production practices and content, using a political economy lens.

At present, there are only a handful of published academic inquiries and analyses related or pertaining to such media products produced in the Cordillera. Ruth Tindaan (2010) looks into how some of the films of the Vernacular Video Ministry, despite being produced for religious or evangelical purposes, battled colonial and mainstream stereotypes of the Igorot (the collective term used to refer to the various indigenous ethnolinguistic groups in the Cordillera region). She writes:

The vernacular films promise alternative representations of the Igorot by showing constructive images such as Igorot characters succeeding through self-reliance and hard work. This runs counter to images of Igorot dependency in mainstream films. The vernacular films also engage in collective history rather than in hero-dominated narrative characteristic of mainstream productions. Furthermore, they also contemplate Igorot cultural practices which are usually used as mere sidelights in mainstream films. (2010, p. 115)

However, she also contends that the films have somehow, perhaps unwittingly, reiterated some colonial imaginaries of Igorots under the 
tropes of animalization and infantilization.

Jimmy Fong (2014) also analyzes how indigenous groups in the Cordillera are articulating their own cultures, traditions, and worldviews through various forms of mass media, including film. He also forwards the idea that the literacy and skills of indigenous peoples of the Cordillera in practicing various types of media production exhibit their intercultural communication competence, which is usually not expected of them under past colonial (or imperial) images and imaginaries.

In a study conducted by Khavee Agustus Botangen, Shahper Vodanich, and Jian $\mathrm{Yu}$ (2017) on the use of Facebook groups by Igorots in the diaspora, they find that among the usual posts that they share are Igorot-produced songs, music videos, and some recorded performances. One of their main observations is that "most contemporary Igorot songs and music videos still depict traditional settings and practices" (p. 2307). Most recent studies on locally produced films in Baguio and Benguet include Jason Paolo R. Telles's $(2018,2019)$ articles that have found that the lyrics, music, and mise-enscene of Kankana-ey music videos with environmental themes were selfrepresentations of the group's spiritual and emotional attachment to nature, their ecocentric perception and treatment of it, and their "cosmovisions" of an ecotopia.

Despite the presence of the abovementioned studies, there is still a large number of research trajectories that could be traversed. Among these is the exploration of the local film production process and the motivation and constraints of the practice in the region, using a political economy lens. This research aims to fill in this gap.

In analyzing the mass media using a political economy lens, it should involve the analysis of the power relations that influence, enable, encourage, shape, restrict, or constrain the conduct and even the ownership of the production of media products (Murdock \& Golding, 1973; Wasko, 2015). In another view, a political-economic analysis of media industries, institutions, and products should not be confined by simply looking into the political and economic influences that shape, motivate, control, or restrain them. Douglas Kellner (2009) proposes that interrogations on the political economy of any form of media should include the exploration of "the economic, political, technological, and the cultural dimensions of the social context in which media industries function" (p. 101).

The local film industries in Baguio City, Benguet, and Mountain Province have been chosen as the focus of this research because they are, as of this writing, among the cities and provinces with more active filmmakers. The film practices of other provinces and cities in the region could be addressed through further studies. 
The sets of data for this paper were gathered through archival research and interviews with the following key informants: Arthur "Art" Tibaldo, a filmmaker and media educator in Baguio City; Rosendo "Sendong" Salvacio and Nestor "Boyong" Daguines, filmmakers from La Trinidad, Benguet; Lemuel W. Fangonon, a Balangao filmmaker from Natonin, Mountain Province; and Gerry Bestoca, a filmmaker from Mankayan, Benguet.

\section{The Process}

The film production practice in Baguio, Benguet, and Mountain Province follows, according to Daguines (personal communication, April 19, 2018), a guerilla filmmaking model. It is characterized by the following: (1) having an "ultra-low-budget," (2) self-funding, and (3) employing or involving of a low number of talents and members of the staff and crew (Ryan, 2015, p. 88). They also have the tendency of not considering needs such as "permission, notification, explanation or remedies for the unexpected" (Wallenstein, 2014, para. 5). In each phase of the production process, local filmmakers in Baguio, Benguet, and Mountain Province follow their own brand of guerilla filmmaking. This section features a descriptive presentation of those activities under each phase. The analysis using a political economy lens is presented in the next section.

\section{The Production}

The process of conceptualization is usually influenced by three factors: the budget, the filmmakers' cultures, and their target audience. Fangonon (personal communication, April 22, 2018) specifically notes, "Kapag nagiisip ako ng gagawing pelikula, inuuna ko ang kuwento na pwedeng gawin sa probinsya, kung kasya ba sa budget" [If I think about the type of film I will produce, I prioritize stories that I could do in our province, if it is within the budget]. Salvacio, on the other hand, claims that when thinking about what to produce, he only considers those that will showcase the following: "mga ugali ng mga Igorot, kultura ng Igorot" [customs of the Igorot people, culture of the Igorot people]. The same is true with Bestoca, who shares that he prefers producing films that exhibit positive community values. Daguines, meanwhile, states that they also consider the interests of their target audiences, which are mostly "Igorots."

After that, they only construct sequence or story guides instead of writing a whole script. In fact, scriptwriting is not really a common practice during the preproduction phase of films produced in the Cordillera. For instance, in Fangonon's Rumah (2015), which was produced in 2015, the production team only used a story or sequence guide as basis for their shoot. This was employed by their actors and actresses as guide for their 
impromptu lines or dialogues (Balangao films, 2016). The same is true with the films made by Daguines and Salvacio.

In terms of financing their films, most film producers and makers in Baguio, Benguet, and Mountain Province fund their own films. Bestoca (personal communication, May 3, 2018) claims that when they produce films, the money they use are "galing sa aming bulsa" [from our own pockets]. When it comes to the amount of the budget for production, Daguines (personal communication, April 19, 2018) says that when compared to the multimillion budgets of mainstream films in Metro Manila, the expenses for each film he made were very low. In fact, he admits that he spent a hundred thousand pesos at the most for the production and reproduction of each of his films. Bestoca (personal communication, May 3, 2018) also allots the same monetary amount. Fangonon (personal communication, April 22, 2018), meanwhile, reveals that the highest budget that he allotted for film production is just three thousand pesos. He explains that he only pays for the equipment he is using and not for their food and transportation. $\mathrm{He}$ states:

Dahil nga sa inuuna namin ang equipment so konti nalang ang natitira para sa merienda. At dahil nga may kanya-kanya kaming baon na pagkain, mas nakakatipid kami. At wala kaming masyadong expense sa transportasyon kasi hindi na kami lumalayo sa lugar namin at kadalasan nilalakad nalang namin papunta sa location.

[Because we prioritize (spending money) for equipment, there are no spare money for snacks. Because we bring our own food, we were able to save money. We do not have much transportation expenses because we do not go far from our own residence. Most of the time, we only walk to our (shooting) location].

There are instances that some politicians have provided financial sponsorships, just like what Salvacio experienced. However, it only covered some of the production costs. Some filmmakers such as Tibaldo have also been financially supported by institutions like the Mowelfund (A. Tibaldo, personal communication, April 21, 2018).

In terms of the number of the talents, crew, and staff, Daguines (personal communication, April 29, 2018) and Salvacio (personal communication, April 29, 2018) say that they only employ a small number. They add that, sometimes, they are the ones doing all the work because of budgetary and logistical constraints. Fangonon (personal communication, April 22, 2018) 
also does this whenever he looks for actors and actresses. He shares that he chooses his close friends. Although they are not paid for their services, they also sometimes assume the roles usually assigned to crew members such as being camera, lights, and sound personnel.

Permits are also not usually acquired by film producers in Baguio, Benguet, and Mountain Province whenever they are using some locations, costumes, and props. Fangonon, Daguines, and Salvacio all explain that they usually choose readily accessible and nearby locations to shoot their films. Also, Fangonon (personal communication, April 22, 2018) was once called to a police station and ordered not to release his film because he used the uniform of the Philippine National Police as a costume without permission. They opted not to gain permits because it would add to their expenses.

\section{Exhibition and Distribution}

Local filmmakers in Baguio, Benguet, and Mountain Province did not and do not have the luxury of being able to exhibit their products in Baguio City's only commercial cinema houses-the four film theaters in SM City Baguio. In the yesteryears, Baguio used to have several cinema houses. All of them went out of business due to various reasons, including the decline in the number of patrons and the entry of the SM mall (Locsin-Afable, 2013). The last local cinemas that eventually closed down during the recent decade are the Empire Cinema along Chugum Street and those that were housed inside the Baguio Center Mall located at Magsaysay Avenue. Even the Cinematheque of the Film Development Council of the Philippines' (FDCP) film exhibition space in Casa Vallejo, which at one time featured a movie produced by Daguines, has closed down. In the experience of Baguio City, local cinema houses became a "Third Space" (or spaces) where Cordillera (i.e., Baguio) locals "define themselves and engage in a continuous creation of culture ..." (Locsin-Afable, p. 77). However, locally produced films were not among those that were exhibited in such spaces.

Due to the lack of opportunity and money by having their films exhibited in commercial cinemas, self-funded and organized exhibitions became practices among some local filmmakers in Baguio, Benguet, and Mountain Province. Some of them organized small screenings in unlikely locations such as the Jacks Social Hall in La Trinidad, Benguet (N. Daguines, personal communication, April 19, 2018). Fangonon, meanwhile, screened his films in small spaces in all eleven barangays in Natonin, Mountain Province (L. Fangonon, personal communication, April 22, 2018).

When it comes to the reproduction and distribution, they rely mostly on VCD or DVD distribution. According to Salvacio (personal communication, April 19, 2018) and Daguines (personal communication, April 19, 2018), 
they and other music video and feature film producers in the area opted to vend their VCDs and DVDs from house to house. They share that they used to hire one vehicle along with some sales personnel, mostly women, to go from one barangay to another to sell their products, which usually turns up good profit. Actual figures of the profit made by local filmmakers in the area are not available because, according to the interviewees in this research, they do not keep official records of their transactions.

At present, some of them chose to look for other cost-effective means and media to distribute their films. The emergence of social media became an open door for them to reach not only audiences in the Cordilleras but also those located in other parts of the Philippines and the world. Bestoca created the YouTube channel "Igorot Channel" where he uploads all his films and music videos for the consumption of many, but he uploaded them not for profit but for posterity and for the purpose of providing inspiration for prospective filmmakers. He shares, "actually for passion lang na gusto kong i-share sa lahat ang mga nagawa ko, sakaling may mga mainspire" [Actually, this is motivated by my passion. I just wanted to share to everybody what I made, just in case someone becomes inspired] (G. Bestoca, personal communication, May 3, 2018). Enrique Olpindo Jr. and Daguines also uploaded their locally-produced animated films on YouTube.

\section{Motivations and Constraints}

Kellner (2009) posits that the determination and interrogation of the "economic, political, technological, and the cultural dimensions of the social context in which media industries function" (p. 101) are important when conducting political economic analyses of various forms of media. These "dimensions" are used in this research as categories of those motivations and constraints influencing and/or hampering the production and distribution of local films in Baguio, Benguet, and Mountain Province. For this specific context, motivations that are economic, political, and cultural are the most evident.

\section{Economic}

A majority of the production of local films in Baguio, Benguet, and Mountain Province, are influenced by economic (i.e., profit-oriented) motivations. For commercial owners and producers, they have ventured into the business of film production to fulfill their agenda for profit generation. Under this type of motivation, Kellner (2009) proposes that "capitalist societies are organized according to a dominant mode of production that structures institutions and practices according to the logic of commodification and capital accumulation" (p. 101). In the same way, 
David Croteau and William Hoynes (2019) mention that "in capitalist systems, mass media organizations must focus on one underlying goal: the creation of products that will earn profits" (p. 142). This objective, they add, can become the basis and springboard of any decision that media producers will make, including those pertaining to content and distribution strategies.

This is evident in the choice of topics or stories produced by local filmmakers in Baguio, Benguet, and Mountain Province. They tend to use those that could capture the attention of a large number of audiences. As a matter of fact, they claim that they usually incorporate content that are emotionally and culturally accessible to their target viewers $(\mathrm{N}$. Daguines, personal communication, April 19. 2018; L. Fangonon, personal communication, April 22, 2018; G. Bestoca, personal communication, May 3, 2018). For example, Daguines (personal communication, April 19, 2018) recalls that when conceptualizing a story, he considers the cultures, beliefs, languages, and practices of his target audiences. He adds that he includes those because his audiences have directly expressed to him that they would like to watch something to which they can relate. As an illustration, Daguines shares his experience of a film that he produced that was, in his term, "nilangaw" or was not able to invite a significant number of viewers. There was one instance when he used the "white lady," a usual character of urban (i.e., horror) legends in the lowlands, as a character in a horror film he made. However, it did not gain much viewership because, as he explains, "hindi sila naniniwala. Siguro [dahil] ginaya ko yung horror ng mga lowlands, hindi sila siguro naka-relate. Dapat ang ginawa ko siguro, dapat yung puro nandito sa Cordillera. Malamang naniwala pa [sila]" [They did not believe it. This maybe because I imitated a horror story from the lowlands. I think they were not able to relate to it. I think I should have used something from the Cordillera. Perhaps, that is something that they would believe.].

The inclusion of local traditions, practices, locations, cultures, and characters is also seen by other filmmakers as a sure-fire way to gain higher profit (R. Salvacio, personal communication, April 19, 2018; Fangonon, personal communication, April 22, 2018). Nestor Clemente, who produced local Christian-themed films, was also quoted in a community paper as saying that his motivations are four-fold-profit, cultural promotion, religion, and self-realization. For his first influence, he specifically said that cinema production is his "bread and butter" (Sumayao, 2011, p. 25). In a way, while having a sublime intention of including, self-representing, and even promoting their localities, cultures, beliefs, traditions, and identities, local filmmakers have also commodified them. Following this thought, the inclusion of elements and aspects of the cultures of the peoples of 
the Cordillera could be seen as a form of "commodification" that seeks to aid those owners of film production businesses in Baguio, Benguet, and Mountain Province to fulfil their economic agenda, that is to gain audiences and, ultimately, garner profit.

However, there are also some local production company owners and filmmakers in the Baguio-Benguet-Mountain Province area who are not influenced by economic or commercial demands. Tibaldo (personal communication, April 21, 2018) says that whenever he is conceptualizing a topic for his documentary films, he is not really visualizing his market. In the same way, Fangonon (personal communication, April 22, 2018) does not mainly aim to gain profit from his films. Whenever he exhibits them in Natonin, Mountain Province, he just collects viewing fees that are worth 30 to 50 pesos. He states, "sa totoo lang libre na sana kaso may mga bayad yung mga sound system at projector kasi nirerentahan lang namin. Hindi naman kami gahaman sa kung may kita o wala. Ang mahalaga kasi sa amin, may manuod at pinapanood" [Honestly, they should have been free but I had to pay for rental fees for the sound system and the projector. We are not greedy, it doesn't matter if we have a profit or not. What's important is that the films are being viewed/watched.].

When it comes to the constraints encountered by local filmmakers in Baguio, Benguet, and Mountain Province, there are also those that are economic in character. Some filmmakers, according to Salvacio and Daguines, have become inactive in producing films due to their losses in terms of sales because of these constraints. One thing that I have noticed in Daguines's (personal communication, April 19, 2018) words is that he continuously claims that the local film industries of Baguio, Benguet, and Mountain Province are "dying." When it comes to the amount of profit from the films that they have produced, Bestoca (personal communication, May 3 , 2018) also claims that it has declined since 2012 due to the entry of a subscription-based Direct-To-Home (DTH) satellite television service in their community. He specifically speaks of the emergence of Cignal as a reason for the decline in their sales. This claim, however, could not be verified as of this time due to the lack of official financial records as filmmakers in the Cordillera do not keep such.

Piracy is also a problem. Fong (2007) writes that, "local piracy has so infested the local music and video market discouraging many of the recording artists and producers" (p. 112). In the same way, Boyong and Sendong shares that pirated copies of their and other producers' films are usually sold cheaper. For example, the original price of a copy of one film is usually 150 pesos while those that are sold in pirated DVD stores inside the Baguio City Public Market are priced 75 to 80 pesos (N. Daguines, personal 
communication, April 19, 2018; R. Salvacio, personal communication, April 19, 2018). Bestoca (personal communication, May 3, 2018) even admitted that they are out of ideas on what to do to address local piracy.

\section{Political}

Political "pressures" and motivations, in their holistic sense, do not only refer to government control and regulation. According to Croteau and Hoynes (2009), the "active role of nongovernment players" (p.219) such as critics, activists, citizen or civic groups, churches, and others, is also "a type of political influence on the media" (p. 219).

In relation to this, it could be observed that the religious advocacies and affiliations of some local film producers also have an influence in their decisions related to conceptualization and distribution. During the first years of local feature film production in Benguet, the primary motivation for production was religious propaganda because the owners of the VVM production ministry are a religious entity. This is evident in the objective of the establishment of the VVM and the production of religious films in the Kankana-ey, Ilocano, and Kalanguya languages (R. Salvacio, personal communication, April 19, 2018; G. Bestoca, personal communication, May 3, 2018; N. Daguines, personal communication, April 19, 2018).

This influence could also be seen in the production of music videos of Protestant Christian songs by peoples of the Cordillera such as those of Pastor Eng-enga (De Velez, Domingo, \& Landicho, 2013). Since he had produced vernacular Christian films, Clemente also claimed that he made them because they promote Christian morality, doctrine, and "God's word" (Sumayao, 2011, p. 25). Fangonon also produced his film A Warrior's Dad to be an official entry for the Christian video making contest organized by Asia Pacific Media PH, an organization that has the mission to "advance the gospel in the Asia Pacific by empowering Christ followers to effectively utilize media and technology" ("About Us - APMedia Philippines," n.d.).

Meanwhile, sources of financial sponsorships do not seem to have an influence in the content decisions of Igorot filmmakers. Fangonon (personal communication, April 22, 2018), who had received sponsorships from some of his kababayan [townmate] that enabled him to purchase good filmmaking equipment, specifically claims, "Kahit may sponsor ang pelikula namin, untouchable pa rin ang aming script. Kung ano ang meron sa script, yun na yun, di na sya magbabago. [Despite having (financial) sponsors, the film script remains untouchable. Whatever is in the script, it will not be changed already]. Salvacio (personal communication, April 19, 2018) also claims that when a politician financed his films, the only thing that the sponsor asked him to give in return is his service as a composer of 
the politician's campaign jingle. He adds that the content of the films were not affected in any way.

The rules, advocacies, and biases of film festival organizers could also be considered external political influences to the conceptualization and production of films by Baguio, Benguet, and Mountain Province locals. Fangonon (personal communication, April 22, 2018) shares that, one time, he had tailor-fitted the content of his film to concur with the advocacy and values of the organizer of the film festival he wanted to join in. He states:

Ang festival ay inorganisa ng isang charity group at ang tema ay tungkol sa pagkakaibigan. Bawal ang mga bastos na salita sa dialogue ng script. Kailangan rated "G" at kelangang ang mga film entry ay inspirational dahil ang mga films ay gagamiting [pang-motivate ng] mga taong may kapansanan na syang tinutulungan ng charity group na ito.

[The festival was organized by a charity group and the theme is about friendship. The use of explicit language in the dialogue was prohibited. It has to be rated "G" and the film entry should be inspiration because they will be used to motivate people with disabilities, who are the beneficiaries of the charity organization].

The same manifested when he joined the Christian organization Asia Pacific Media PH's film festival in 2017, where he submitted his Christian film $A$ Warrior's Dad (2017), and the GMA Network's Encantadia fan fiction contest in 2016, where he submitted his short feature films Artal (2016) and Etherian (2016) which were aptly based on the television network's teleserye Encantadia.

Perhaps the only political constraint in local film production in Baguio, Benguet, and Mountain Province related to government regulation is a rule/action of the Optical Media Board (OMB) of the Philippines against piracy. According to Salvacio and Daguines, the OMB strictly regulated the sale of blank VCDs, DVDs, and their cases or containers, which directly affected the reproduction (i.e. "burning") of local films and their sales. The licensed suppliers of blank optical media discs, meanwhile, who continued to sell such have raised their prices, making them less accessible to local filmmakers who have minimal budget for production, reproduction, and marketing (N. Daguines, personal communication, April 19, 2018; R. Salvacio, personal communication, April 19, 2018). 


\section{Cultural}

Going beyond being mere tools of information, education, and entertainment, films have a role in presenting and representing the realities, ideologies, cultures, and worldviews of those who produce and consume them. Croteau and Hoynes (2019), in fact, state that "some researchers investigate media content as a gauge of social norms, values, and the interests of society in general-not just the audience" (p. 337). Locally-produced films in the Cordillera, in this sense, could also be seen as reflections (or self-representations) of the cultures-or the ways of life embodied or represented through tangible and intangible artifacts such as norms, values, beliefs, traditions, and practices, among others-of those who produce and directly consume them, most of which are members of indigenous ethnolinguistic groups in the Cordillera.

Several other scholars have also argued that films produced by indigenous peoples could be deemed as self-representations of their cultures, identities, ideologies, and worldviews. Jennifer Machiorlatti (2010), in her research about the filmmaking activities and products of the Native Americans of the United States and the First Nations of Canada, describes such practices as a "cinematic extension of the oral tradition" (p. 63) of those indigenous groups. Faye Ginsburg (2002), meanwhile, suggests that indigenous-produced audiovisual media products could be considered as "screen memories." This concept states that indigenous peoples:

....are using screen media not to mask but to recuperate their own collective stories and histories-some of them traumatic-that have been erased in the national narratives of the dominant culture and are in danger of being forgotten within local worlds as well (p. 40).

Also, such media products, according to Joni Adamson and Salma Monani (2016), provide us with a view of indigenous peoples' "cosmovisions," or those "conceptions of entangled human relations with more-than-human worlds" (p. 3).

Likewise, Jimmy B. Fong (2014) acknowledges that films and other forms of mass media have been used by indigenous peoples in the Cordillera to represent themselves, their cultures, and identities, as well as to display their competency in intercultural communication. He specifically notes how they have utilized filmmaking, music recording, radio broadcasting, and the Internet, among others, in representing themselves. Such production practices have become responses, consciously and unconsciously, to the misrepresentations that have proliferated against them through the years, 
which are negative, colonial, and imperial in character and origin (Tindaan, 2010; Fong, 2014).

In relation to this, it could be seen that the ethnolinguistic affiliation and cultural advocacies of local film producers, most of them claim to be members of indigenous groups, also influence their production practices. As such, self-representation, whether it is a conscious or unconscious effort, is a primary motivation. Groyon (2014), in his review of the participant films in the Cinemarehiyon 2009 from the Cordillera, observes that local producers from the region "have turned to their culture and heritage, making it the central character of their films" (p. 184). For Fangonon (personal communication, April 22, 2018), one of his motivations for producing his feature films is to promote and represent his Balangao culture and residence. He specifically says, "Ang iniisip kong audience at target audience ko na rin ay ang mga tao na hindi parte ng aming tribo dahil gusto kong i-promote ang aming kultura at ang aming lugar. [I visualize my target audience as those who are not members of our tribe because I would like to promote our culture and our place].

Salvacio (personal communication, April 19, 2018) also claims his Kankana-ey root has an influence in his stories. He particularly shares that such stories are "madaling isulat" [easy to write] because of their emotional and even physical proximity to him. He adds that choosing stories that are based on his and his target audiences' cultures, traditions, and beliefs are beneficial in communicating and promoting them. For example, the film Bosu: The Last Headhunter (2015) features the practices and traditions of some indigenous ethnolinguistic groups in the Cordillera and is inspired by the stories in their communities (Empian, 2015). In a news item published by the Baguio Midland Courier, Daguines is quoted as saying that the film is "not a true story but is based from others' experiences and the stories that [they] have heard from [their] elders" (Empian, 2015). Clemente also claims in an interview for a community newspaper that cinema production is a method where he is "promoting Igorot culture as well as preserving it" (Sumayao, 2011, p. 25).

\section{Conclusion}

The realization and articulation of the histories, state, political economy, and futures of film industries from the regions are significant projects for the understanding of the whole context of national cinema in the Philippines. It is through those information that we could aim for a decentralized (i.e., non-Manila centric) view of national cinema that, according to Miguel Rapatan (2017), "embodies and celebrates the complexity, diversity, and depth of Philippine culture" (p. 91). This article, by providing a preliminary 
understanding of just one segment of the film landscape in the Cordilleras, aims to aid in the growth of such discourse. By using the local filmmaking industries of Baguio, Benguet, and Mountain Province as case studies, this article takes the role of being an open door for future researchers to explore a more holistic comprehension of the region's rising film industries.

In sum, this paper has found that the local film industries of and in Baguio, Benguet, and Mountain Province are influenced and are being shaped by motivations and constraints that are economic, political, and cultural in character. Specifically, religious propaganda, commercial interests, advocacies for cultural self-representation and promotion, and impositions of film festivals have become the main influences in the conceptualization, production, and distribution phases/stages of local films in those city and provinces. Meanwhile, piracy, the state's strict regulation of the sale of blank optical media discs, and financial constraints, have contributed to the hampering of the growth and development of the local cinema industry in the area.

This paper, however, does not aim to offer a complete perspective of the film industries in Baguio, Benguet, Mountain Province, and the rest of the Cordillera region. There are narratives and perspectives that are yet to be recorded and analyzed. In provinces like Ifugao and Kalinga, there exist moderately active local cinemas. In my interview with Fangonon, he also shares that there were films produced by Ifugao peoples that he was able to watch during his childhood. The budding local film industry of Abra is also one that should be explored. Perhaps there are more, even in Apayao, and they also all deserve to be discussed and analyzed.

It would also be interesting to locate the roles and contributions, as well as the political economy, of independent films produced by mass communication or communication students in universities in Baguio City and other localities in the Cordilleras. Finally, the audiences and their consumption of Cordilleran-produced films could also be traversed in future researches. Textual analyses of films, such as those previously read by Tindaan (2010) and Telles $(2018,2019)$, should also be done to give more light to how such media products have become grounds or spaces where locals and peoples of the Cordillera have begun to articulate and mediate their own cultures and identities, as well as to resist those imageries and imaginaries that have been used to represent them especially in mainstream films and other related forms of media. 


\section{References}

About us - AP Media Philippines. (n.d.). http://www.apmedia.org/ph/about/

Adamson, J., \& Monani, S. (2016). Introduction: Cosmovisions, ecocriticism, and indigenous studies. In S. Monani \& J. Adamson (Eds.) Ecocriticism and indigenous studies: Conversations from Earth to cosmos (pp. 1-23). Routledge.

Balangao films. (2016, July 26). 5 things you should know about Rumah movie [Blog post]. https:// balangaofilms.wordpress.com/2016/07/26/5-things-you-should-know-about-rumah-movie/

Botangen, K. A., Vodanich, S., \& Yu, J. (2017). Preservation of indigenous culture among indigenous migrants through social media: The Igorot peoples. In Proceedings of the 50th Hawaii International Conference on System Sciences, (pp. 2303-2312). IEEE.

Campos, P. F. (2015). Kidlat Tahimik and the determination of a native filmmaker. Kritika Kultura, 25, 46-81. Croteau, D., \& Hoynes, W. (2019). Media/Society: Technology, industries, content, and users (6th ed.). Sage.

Cruz, M. (2020, September 30). Abrenian Heritage film fest expands its reach for 2 nd edition. Inquirer. https://entertainment.inquirer.net/392148/abrenian-heritage-film-fest-expands-its-reach-for2nd-edition

Dagu-pen, R. (2017, December 27). MPGCHS to represent Cordillera in film festival. SunStar Baguio, p. 2. De Velez, K. B., Domingo, H. J. S., \& Landicho, L. M. (2013). Recording Igorot-ness through Igorot-made music videos [Unpublished undergraduate thesis]. University of the Philippines Baguio, Baguio City, Philippines.

Empian, O. C. (2015, July 19). Igorot indie film to be shown in Cinema Rehiyon in Cebu. Baguio Midland Courier. http://www.baguiomidlandcourier.com.ph/ life.asp?mode=\%20archives/2015/july/7-19-2015/life4-Igorot-indie-film.txt

Fong, J. B. (2007). Batawa: Constructing identity through country music in the Philippine Cordillera. In Inter: A European cultural studies conference (pp. 109-119). Linköping University Electronic Press. http://www.ep.liu.se/ecp/025/013/ecp072513.pdf.

Fong, J. B. (2014). Media production literacy as a form of intercultural communication competence: Demystifying indigenous peoples in the Philippine Cordillera. In X. Dai \& G. Chen (Eds.), Intercultural communication competence: Conceptualization and its development in cultural contexts and interactions (pp. 275-292). Cambridge Scholars Publishing.

Ginsburg, F. D. (2002). Screen memories: Resignifying the traditional in indigenous media. In F. D. Ginsburg, L. Abu-Lughod, \& B. Larkin (Eds.), Media Worlds: Anthropology on New Terrain (pp. 39-57). University of California Press.

Groyon, V. G. (2014). Cinemarehiyon 2009. In J. Chua, R. Cruz-Lucero, \& R. B. Tolentino (Eds.), A Reader in Philippine film: History and criticism (pp. 177-196). University of the Philippines Press.

Hua, X., Lu, L., \& Zhang, H. (2004). Automatic music video generation based on temporal pattern analysis. In MULTIMEDIA '04: Proceedings of the 12th annual ACM international conference on multimedia (pp. 472-475). Association for Computing Machinery. https://doi.org/10.1145/1027527.1027641

Kellner, D. (2009). Media industries, political economy, and media/cultural studies: An articulation. In Jennifer Holt \& Alisa Peren (Eds.), Media industries: History, theory, and method (pp. 95-107). Blackwell Publishing. 
Local megmen sweep awards in docu tilt. (1985, May 18). The Gold Ore, pp. 1, 3.

Locsin-Afable, M. R. A. (2013). A brief history of the Baguio sine. Plaridel, 10(1), 64-81.

Machiorlatti, J. A. (2010). Ecocinema, ecojustice, and indigenous worldviews: Native and first nations media as cultural recovery. In P. Willoquet-Maricondi (Ed.), Framing the world: Explorations in ecocriticism and film (pp. 62-82). University of Virginia Press.

Manovich, L. (1999). What is digital cinema? In P. Lunenfeld (Ed.), The digital dialectic: New essays on new media (pp. 172-196). The MIT Press.

Matilla, D. R. (2015, September 21). Kidlat Tahimik: 'Let the local come, that's what the world is waiting For'. Inquirer.Net. http://lifestyle.inquirer.net/207238/kidlat-tahimik-let-the-local-come-thats-whatthe-world-is-waiting-for/

Murdock, G., and Golding, P. (1973). For a political economy of mass communications. Socialist Register, 10, 205-234. http://www.socialistregister.com/index.php/ srv/article/view/5355/2256\#.Wu6qsC-B3_Q

National Commission for Culture and the Arts. (2015). Seventeen films to grace Cinema Rehiyon 7 in Cebu. http://gwhs-stg02.i.gov.ph/ s2govnccaph/press-releases-2/seventeen-films-to-gracecinema-rehiyon-7-in-cebu/

OMICS International. (2014). List of radio stations in Cordillera Autonomous Region. http://research. omicsgroup.org/index.php/List_of_radio_stations_in_Cordillera_Autonomous_Region

Rapatan, M. (2017). Regional cinema: 1938-2014. In Cultural Center of the Philippines Encyclopedia of Philippine Art, Volume 6: Film (pp. 82-91). Cultural Center of the Philippines.

Ryan, M. D. (2015). From Aussiewood movies to guerrilla filmmaking: Independent filmmaking and contemporary Australian cinema. In D. Baltruschat \& M. P. Erickson (Eds.), Independent filmmaking around the globe (pp. 71-89). University of Toronto Press.

Sumayao, R. (2011, August-September). The advent of Benguet movies \& music videos. Agshan Community Newspaper, p. 25.

Telles, J. P. (2018). Imaging indigenous relationships with nature: The case of Igorot music videos. In J. C. Ryan (Ed.) Southeast Asian ecocriticism: Theories, practices, prospects (pp. 87-112). Lexington Books.

Telles, J. P. (2019). Through indigenous lenses: Ecotopia according to vernacular music videos from Benguet, Philippines. Utopian Studies, 30(1), 45-66.

Tindaan, R. M. (2010). Imaging the Igorot in vernacular films produced in the Cordillera. The Cordillera Review, 2(2), 81-118.

Wallenstein, J. (2014, December 31). "Guerrilla" filmmaking is inherently risky. Huffington Post. https:// www.huffingtonpost.com/joe-wallenstein/guerrilla-filmmaking-is-i_b_6373390.html

Wasko, J. (2015). How Hollywood works (2nd ed.). Sage. 


\section{Note}

${ }^{1}$ This article is an expanded version of the author's final paper for his Media 250 (Political Economy of Media) class under Prof. Rolando B. Tolentino during the Second Semester, A.Y. 2017-2018. 


\section{Grant Support Details}

Author Contributions: All research activities and writing were done by J.P. Telles. The author has read and agreed to the published version of the manuscript.

Funding: The author received no specific funding for this work.

Acknowledgements: The author would like to thank all the key informants (local filmmakers in Cordillera) who provided the primary data for this research-Nestor Daguines, Rosendo Salvacio, Arthur Tibaldo, Lemuel Fangonon, and Gerry Agyao Bestoca.

Conflict of Interest: The author declares no conflict of interest.

\section{About the Author}

JASON PAOLO TELLES teaches broadcast communication, communication, and media studies at the University of the Philippines Baguio (corresponding author: jrtelles@up.edu.ph). 